\title{
THE FORMATION OF NITROGEN-FIXING ROOT NODULES BY SOYBEAN PLANTS UNDER THE USE OF POST-EMERGENCE HERBICIDES, PLANT GROWTH REGULATOR AND MICROFERTILIZER
}

\section{R. A. Gutyanskyi}

It is impossible to get high yield of soybean without the use of herbicides [1]. Today, farmers are paying great attention to the application of the system of insurance (post-emergent) herbicides in soybean crops. This is due to the fact that during the growing season crops it is easier to determine the level and type of weed-infestation and therefore, based on the species composition of weeds, you can select specific herbicides. The use of tank mixes of post-emergent herbicides in small norms in the early phases of weeds development is relevant for soybean protection from weeds. This not only increases the economic and herbicidal efficacy, but also makes it possible to significantly reduce the after-effect of some herbicides on these crops and crop rotation to avoid weed resistance to the active ingredient of the preparation $[2 ; 3]$.

Also farmers' attention in Ukraine is increasing to growth regulators and micronutrients. This contributes to creating growth-stimulating preparations of a new generation that are characterized by high efficiency and environmental safety [4].

Based on the foregoing, much of the research of the use of post-emergent herbicides, growth regulators and micronutrients in crops of soybeans is aims to study their effect on the yield of crops. However, the impact of these preparations on the formation of nitrogen-fixing nodules on soybean roots is neglected, although such research is relevant [5]. So, the objective of the research was to study the effect of tank mixes of post-emergent herbicides and combinations of growth regulators and fertilizers on soybean plants ability to form nitrogen-fixing nodules, biomass and yield.

Materials and methods. The rsearch was performed during the 2012-2014 at the laboratory of plant production of the Plant Production Institute named after V. Ya. Yuryev of NAAS. In field experiments herbicides Nabob, Tabezon bentazone, $480 \mathrm{~g} / \mathrm{l}$ ), Fabian (imazethapyr, $450 \mathrm{~g} / \mathrm{kg}+$ chlorimuron-ethyl $150 \mathrm{~g} / \mathrm{kg}$ ), Serp (imazethapyr, $100 \mathrm{~g} / \mathrm{l}$ ) Fussilade Forte 150 EC (fluazifop-P-butyl
$150 \mathrm{~g} / \mathrm{l}$ ), Pantera, Lemur (quizalofop-P-tefuryl, $40 \mathrm{~g} / \mathrm{l}$ ) Miura (quizalofop-P-ethyl, $125 \mathrm{~g} / \mathrm{l}$ ) and Proponit 720 (propizochlor, $720 \mathrm{~g} / \mathrm{l}$ ) were studied. Plant growth regulator Atonik Plus was used (5-sodium nitroguaiacolat, $3 \mathrm{~g} / \mathrm{l}+$ sodium ortho-nitrophenolate, $6 \mathrm{~g} / \mathrm{l}+$ sodium para-nitrophenolate, $9 \mathrm{~g} / \mathrm{l}$ ) and Nanomix microfertilizer with the complex of bio-stimulants ( $\mathrm{N}-$ up to $3.0 \% ; \mathrm{K}_{2} \mathrm{O}-$ up to $3.5 \%$; Fe (OEDP) - 0.2-0.7\%; Fe (EDTA) $0.2-0.7 \%$; Mn (OEDP) - 0.1-0.7\%; Mn (EDTA) - $0.1-0.7 \%$; Zn (OEDP) - up to $0.65 \%$; Zn (EDTA) - $0.1 \neg 0.65 \%$; $\quad \mathrm{Cu} \quad($ EDTA) $0.05-1.2 \%$; Co (EDTA) - 0.004-0.05\%; B (OEDP) - $0.05 \neg 0.8 \%$; Mo (OEDP) $0.01-0.05 \%$; $\mathrm{Mg}$ (EDSA) - 0.5-0.8\%; $\mathrm{CaO}-$ $0-1.0 \%$; $\mathrm{S}-1.5-3.7 \%$ ) [4]. The preparations were administered with the help of knapsack sprayer with the working fluid flow of $300 \mathrm{l} / \mathrm{ha}$. Control - sowing without the use of herbicides, growth regulators and fertilizers.

Research field soil - common heavy loamy black soil. The reaction of soil solution $(\mathrm{pH})$ 5.8; hydrolytic acidity - $3.29 \mathrm{mg}$. eq. per $100 \mathrm{~g}$ of soil; the amount of absorbed bases $-37.4 \mathrm{mg}$. eq. per $100 \mathrm{~g}$ of soil. Stocks in soil: nitrogen $164 \mathrm{mg} / \mathrm{kg}$, phosphorus $-109 \mathrm{mg} / \mathrm{kg}$, potassium - $119 \mathrm{mg} / \mathrm{kg}$.

Precursor - winter wheat. Romantyka variety soybean was sown with the width of 45 cm between rows. $\mathrm{N}_{30} \mathrm{P}_{30} \mathrm{~K}_{30}$ was administered before pre-sowing cultivation. Plot accounting area - $36 \mathrm{~m}^{2}$, repetition - three-fold. Agrotechnics in experiments is common for growing zone [6], except for agricultural measures that were studied.

The accounting of nitrogen-fixing soybean nodules was performed according to H. S. Posypanov method [7]. Along with nodules accounting the crude mass of plants was determined. Soybean seeds harvesting was performed by direct combine harvesting by combine harvester "Sampo-130". The research results were statistically processed by correlation and variance analysis [8].

Meteorological conditions during the research were the following: the total amount of 
rainfall from May to August in 2012, 2013 and 2014 amounted to 205, 211 and $319 \mathrm{~mm}$ and the average temperature for this period - $21.8 ; 21.9$ and $21.3^{\circ} \mathrm{C}$ respectively.

Thus, based on the results of research it must be concluded that the use of tank mixes of post-emergent herbicides in soybean crops produces negative effect on the formation of nitrogen-fixing nodules on the root system of the culture, and the formation of their mass. The combination of Atonik Plus plant growth regulator and Nanomix microfertilizer with post-emergent herbicides contributed to the increase in the amount of crude and dry mass of nodules on the roots of soybeans. Soybean plants mass grew against the background of herbicide tank mixes Nabob+Fabian+Miura and Nabob+ Fussilade Forte 150 EC and Atonik Plus and Nanomix stimulators. The largest yield of the culture was formed by using of herbicides tank mixes Nabob+Fabian+Miura and Nabob+ Fussilade Forte 150 EC. The combination of Atonik Plus plant growth regulator and Nanomix microfertilizer with post-emergent herbicides reduced the effectiveness of the latter against weeds that prevented from the revealing soybeans crop potential. 